\title{
The GIS Application of Marine Protected Area Site Selection, in Trenggalek, East Java Province
}

\author{
Dhira K. Saputra \\ Department of Marine Science \\ Marine Science, Brawijaya University, Malang \\ Malang, Indonesia \\ Corresponding email: dhira.ks@gmail.com \\ Sukandar \\ Department of Marine Science \\ Marine Science, Brawijaya University, Malang \\ Malang, Indonesia \\ Muliawati $\mathrm{H}$. \\ Department of Marine Science \\ Marine Science, Brawijaya University, Malang \\ Malang, Indonesia \\ Citra Satrya U. \\ Department of Marine Science \\ Marine Science, Brawijaya University, Malang \\ Malang, Indonesia \\ Wahyu P. Pratama \\ Department of Marine Science \\ Marine Science, Brawijaya University, Malang \\ Malang, Indonesia \\ Anthon Andrimida \\ Department of Marine Science \\ Marine Science, Brawijaya University, Malang \\ Malang, Indonesia
}

\begin{abstract}
Marine Protected Area (MPA) is one of the best tools for maintaining coastal fisheries sustainability. District of Trenggalek, which has $96 \mathrm{~km}$ coastline and 57 small islands, categorized as one of most productive coastal areas in Southern coast of East Java. On the other hand, the demand of MPA in this region become urgent as the decline on its coastal natural resources in recent years. Methods used in this research include: site suitability analysis using GIS multi-criteria analysis, divided into three criteria: ecology, socio-cultural and economy. Ecological survey and data ground check conducted in three locations, Bay of Panggul (Panggul), Bay of Sumbreng (Munjungan) and Bay of Prigi (Watulimo). Focus Group Discussion (FGD) with key stakeholders to obtain more precise information, continued with set of scoring and weighting (data analysis) to obtain MPA's site suitability and category. The results show high suitability areas for MPA includes Wonocoyo, Munjungan, Karanggandu and Karanggongso. Each site has a high value in ecological criteria (ecosystem and biodiversity),
\end{abstract}

social criteria (social acceptance) and economic criteria (importance to species and value for marine tourism).

Keywords-Coastal conservation, environmental planning, GIS, mangrove, coral reef

\section{INTRODUCTION}

Marine Protected Area (MPA) or Marine Conservation Area (MCA) describes as the areas of waters including flora, fauna, cultural and historical patterns associated with all variables mentioned, are protected by law or other effective policies, which aimed to protect part or all of the surrounding environment (Kelleher, 1999). Clark (1996) describes the purpose of MPA, includes (1) maintaining the quality of the environment, (2) Protecting species diversity, (3) protect ecologically sensitive areas, (4) protecting critical habitat and (4) the adaptive strategies of hazards through conservation. 
Need of MPA is unavoidable, because of the condition of world fisheries are already hugely depleted (FAO, 2008). Roberts (2007) stated that to obtain $1 \mathrm{~kg}$ of fish consumption, fishermen have destroyed more than $20 \mathrm{~kg}$ of fish resources includes their habitat.

In Indonesia, MPA is the main program of coastal resource management. Reference legislation used for MPA includes Law No. 31/2004, as revised by Law No. 45/2009 on Fisheries, Law No. 32/2014 on Local Government, Law No.27/2007 jo Law No.1/2014 on the Management of Coastal Areas and Small Islands, and some of Regulation Government (PP), includes PP 30/2010 on Zoning Management Plan and Water Conservation Area.

POKMASWAS is a local community inspector group, which is a component of society that could potentially participate actively in fisheries surveillance and may consist of elements of religion, elements of traditional, fishermen, farmers and entrepreneurs in the field of fisheries. POKMASWAS establishment constituted by Law No. 31/2004 Article 67 on Fisheries; Law No. 32/2004 on Regional Government; Regulation of the Minister of Marine Affairs and Fisheries No. KEP.58/MEN/2002 on SISWASMAS (Supervisory Systems Society). In fact, POKMASWAS plays a vital part in the monitoring the use of coastal natural resources, which is the heart of coastal conservation.

\section{METHOD}

MPA site selection variables based on Government Decree No. 60/2007 Article 8, paragraph 3 consist of following criteria: (A) Ecology: include biodiversity, naturalness, ecological relevance, representativeness, uniqueness, productivity, migratory habitat, protected fish habitat, fish spawning areas, and areas of care; (B) Social and cultural: include the level of community support, potential conflicts of interest, potential threats, local wisdom and customs; and (C) Economy: include the importance of fisheries, recreation and tourism potential, aesthetics, and ease of reaching the region. This criteria similar with Salm et al. (2000).

TABLE I. MPA SITE SELECTION CRITERIA

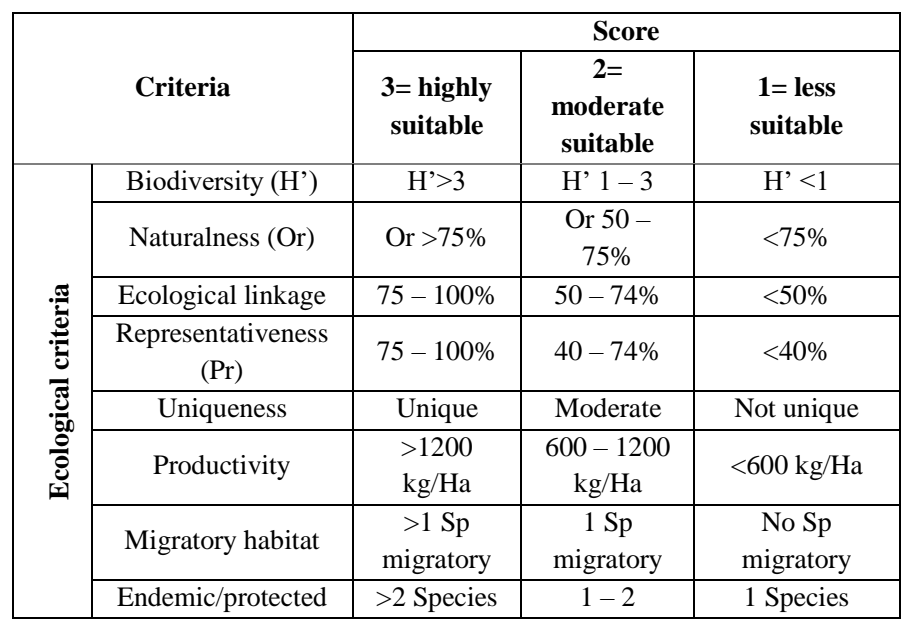

\begin{tabular}{|c|c|c|c|}
\hline \multicolumn{2}{|c|}{ Criteria } & \multicolumn{3}{|c|}{ Score } \\
\cline { 2 - 5 } & $\begin{array}{c}\mathbf{3 =} \text { highly } \\
\text { suitable }\end{array}$ & $\begin{array}{c}\mathbf{2 =} \\
\text { moderate } \\
\text { suitable }\end{array}$ & $\begin{array}{c}\text { 1= less } \\
\text { suitable }\end{array}$ \\
\hline species habitat & Species & 1 area \\
\hline Spawning ground & 2 areas & 2 areas & None \\
\hline Nursery ground & $\begin{array}{c}\text { Mangrove } \\
\text { and } \\
\text { seaweed }\end{array}$ & $\begin{array}{c}\text { Mangrove } \\
\text { or seaweed }\end{array}$ & \multicolumn{2}{|c|}{ Source: KKP, 2016 } \\
\hline
\end{tabular}

\begin{tabular}{|c|c|c|c|c|}
\hline & \multirow[b]{2}{*}{ Criteria } & \multicolumn{3}{|c|}{ Score } \\
\hline & & 3= highly & $\begin{array}{c}2= \\
\end{array}$ & $1=$ less \\
\hline \multirow{4}{*}{ 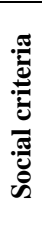 } & Social acceptance & $>75 \%$ & $40-75 \%$ & $<40 \%$ \\
\hline & Threat & $<2$ threats & $\begin{array}{c}2-5 \\
\text { threats }\end{array}$ & $>5$ threats \\
\hline & Potential conflict & Low & Moderate & High \\
\hline & Local customs & Effective & $\begin{array}{c}\text { Less } \\
\text { Effective }\end{array}$ & $\begin{array}{c}\text { Not } \\
\text { available }\end{array}$ \\
\hline \multirow{3}{*}{ 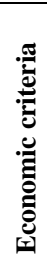 } & $\begin{array}{c}\text { Fisheries } \\
\text { importance (LQ) }\end{array}$ & $>1$ & 1 & $<1$ \\
\hline & Tourism value & $>3$ & $1-3$ & $\begin{array}{c}\text { Not } \\
\text { available }\end{array}$ \\
\hline & Ease of access & $\geq 75 \%$ & $41-74 \%$ & $\leq 40 \%$ \\
\hline
\end{tabular}

Prior to the field survey, several satellite images processing performed to identify critical habitat, especially mangrove and coral reef, as presented in the following table.

TABLE II. MAPS, SATELLITE IMAGERY AND PROCESSING METHODS

\begin{tabular}{|c|c|c|c|}
\hline No. & Maps & Satellite image & Methods \\
\hline $\mathbf{1}$ & Mangrove & Landsat 8 OLI & $\begin{array}{c}\text { False color } \\
\text { composite band 564 }\end{array}$ \\
\hline $\mathbf{2}$ & Coral reef & Landsat 8 OLI & $\begin{array}{c}\text { Lyzenga algorithm } \\
\text { (Lyzenga, 1978) }\end{array}$ \\
\hline $\mathbf{3}$ & Topography & $\begin{array}{c}\text { SRTM/TOPEX } \\
\text { Poseidon }\end{array}$ & Contour extraction \\
\hline $\mathbf{4}$ & Bathymetri & Topex Poseidon (2015) & Contour extraction \\
\hline $\mathbf{5}$ & $\begin{array}{c}\text { Land Use-Land } \\
\text { Cover }\end{array}$ & $\begin{array}{c}\text { Landsat 8 OLI } \\
\text { classification }\end{array}$ \\
\hline $\mathbf{6}$ & Road & $\begin{array}{c}\text { RBI Database (BIG, } \\
\text { 2014) }\end{array}$ & $\begin{array}{c}\text { Vector analysis } \\
\text { (2014) }\end{array}$ \\
\hline
\end{tabular}

Coastal critical habitat which categorized as conservation feature made up of mangroves and coral reefs, analyzed using false color band combination (5-6-4) and Lyzenga algorithm respectively. The image classification was done by observing the differences in the spectral responses and image contrast. Visual analysis is done to improve the accuracy in the identification of habitat locations, using both habitat and topobathymetric maps combined with Google Earth. Land UseLand Cover (LU-LC) mapping was performed by maximum supervised likelihood algorithm. 
There are four sites selected for the field survey, based on the reference obtained from image analysis, includes Wonocoyo village (located in Bay of Panggul), Munjungan village (Bay of Sumbreng), Karanggandu and Tasikmadu villages (Bay of Prigi).

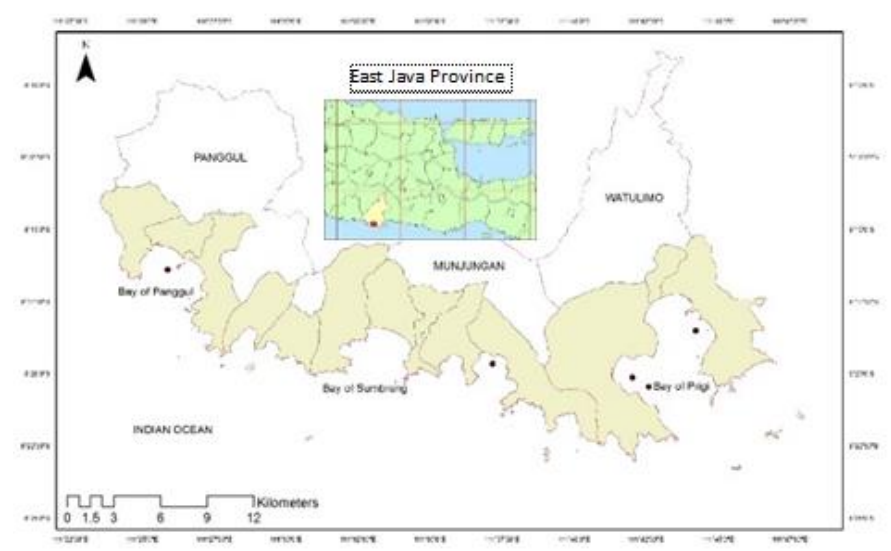

Fig. 1. Map of study areas

The locations visited in October 2016 to obtain more indepth information related to the MPA criteria. Ecological survey for mangrove and coral reef refers to standard survey methods from English, et al. (1997), while socio-economic informations obtained from interviews with key-stakeholders (POKMASWAS) and local communities. POKMASWAS role as key stakeholders who assumed to provide in-depth information on social situations. Other stakeholders involved are regional government (Department of Marine Affairs and Fisheries of Trenggalek) and local communities.

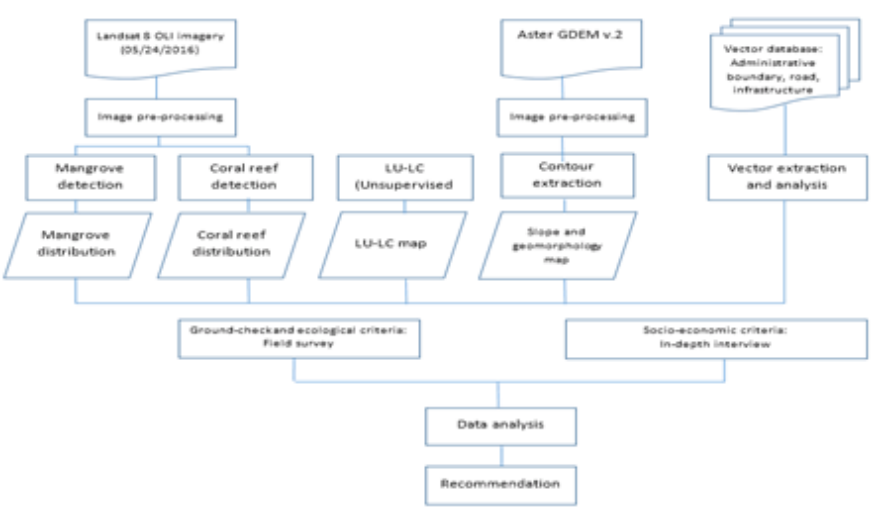

Fig. 2. Data processing and field observation.

\section{FINDING AND DISCUSSIONS}

\section{A. Geomorphology and coastal ecosystems}

Geomorphological map extracted from Aster GDEM v.2 indicates the hilly contours along coast of Trenggalek, reflected a typical characteristics of uplifted landforms from the result of tectonic formations, which located near plate subduction zone, southern coast of Java. The coastal landforms characterized by small bays bounded by cliff coasts with strong hydro-oceanography and dissipative regions. Contour roughness causing difficulty of road access to the most beach in Trenggalek. Gentle slopes located in the divergence zone of the four biggest bays, the Panggul, Sumbreng, Damas and Prigi at the center of human activity and ruled as capital of all three coastal districts (Panggul, Munjungan and Watulimo). This condition produces patchy distribution in coastal ecosystems. Substrate predominantly composed by sand. Water quality visually categorized in good conditions, characterized by a high brightness and the lack of discharge from major rivers.

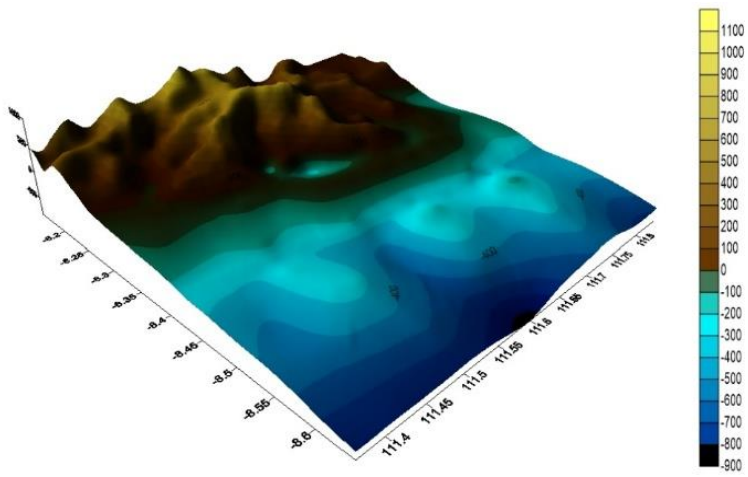

Fig. 3. Slope and bathymetry map of Trenggalek

From the false color composite, the mangrove can be differentiated from other features such as terrestrial forest, agriculture area and human settlements. Visual interpretation from Landsat 8 OLI imagery identify the mangrove distribution along coast of Trenggalek with a total area of 44 Ha. Biggest extent of mangrove located in Pancer Cengkrong, mudflat region in Watulimo sub-district (44 Ha).

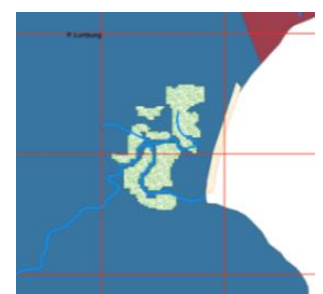

(a)

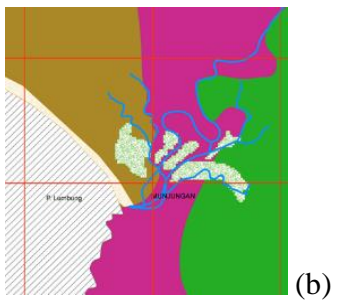

Fig. 4. a) Mangrove distributions in Blado (Munjungan) and b) Pancer Cengkrong (Watulimo).

Coral reefs are scattered particularly in the sheltered regions, with an area of narrow, elongated in the front of the cliffs or surrounding the rock islands. An abundant amount of cliff caves, sea stacks and wave-cut formations alongside Trenggalek coasts provide favorable habitats for lobster (Panulirus spp.). All three coastal habitats (mangroves, coral reef and lobster's cliff caves) formed categorized as primary conservation features in coastal ecosystems of Trenggalek. Field survey resulted in the identification of ecological conditions at each location, as presented in Table 3. 
TABLE III. FIELD SURVEY RESULT FOR ECOLOGICAL CRITERIA

\begin{tabular}{|c|c|c|c|c|}
\hline \multirow{3}{*}{ Variable } & \multicolumn{4}{|c|}{ Regions } \\
\hline & Panggul & Munjungan & & limo \\
\hline & T. Kili Kili & Munjungan & Karanggandu & Tasikmadu \\
\hline Naturalness & $\begin{array}{l}>75 \% \\
\text { The Isle of Godho is the primary } \\
\text { habitat for lobster and coral reef. } \\
\text { Coastal vegetation in turtle } \\
\text { nesting sites includes } \\
\text { rehabilitation area of P. tectorius } \\
\text { and C.equisetifolia }\end{array}$ & $\begin{array}{l}>75 \% \\
\text { Most part of coral reefs (in } \\
\text { Bendoroto) and mangrove in } \\
\text { Blado categorized as natural } \\
\text { habitat }\end{array}$ & $\begin{array}{l}<40 \% \\
\text { Mangrove Pancer Cengkrong } \\
\text { rehabilitation area since } 2002\end{array}$ & $\begin{array}{l}>75 \% \\
\text { Reef in Isle of Rembeng, Karang } \\
\text { Malang and Songdruwo beach } \\
\text { categorized as natural. Coral } \\
\text { transplantation located in } \\
\text { Besetan beach }\end{array}$ \\
\hline Diversity & Moderate & Moderate & Moderate & moderate \\
\hline $\begin{array}{l}\text { Ecological } \\
\text { linkage }\end{array}$ & $\begin{array}{l}\text { Kili Kili: highly suitable as turtle } \\
\text { landing and nesting site } \\
\text { Isle of Godho: favorable habitat } \\
\text { for lobster }\end{array}$ & $\begin{array}{l}\text { Blado estuary: riverine } \\
\text { mangrove } \\
\text { Bendoroto: high suitability } \\
\text { for coral reef habitat }\end{array}$ & $\begin{array}{l}\text { Pancer Cengkrong: largest } \\
\text { mudflat for true mangrove }(C \text {. } \\
\text { decandra, } A . \text { marina, } \\
\text { Xylocarpus sp. and } S \text {. }\end{array}$ & $\begin{array}{l}\text { Carbonate deposit substrate and } \\
\text { sheltered region in } \\
\text { Karanggongso as ideal habitat } \\
\text { for coral reef, reef fish,lobster } \\
\text { and megabenthos }\end{array}$ \\
\hline $\begin{array}{l}\text { Representative } \\
\text { ness }\end{array}$ & $\begin{array}{l}>75 \% \\
\text { Kili Kili: sandy beach completed } \\
\text { with } P \text {. tectorius } \\
\text { Isle of Godho: rock isle with sea } \\
\text { cave }\end{array}$ & $\begin{array}{l}>75 \% \\
\text { Blado: River with high } \\
\text { organic matter deposit } \\
\text { Bendoroto: sheltered bay and } \\
\text { bedrock formations } \\
\text { Cliff coasts and offshore isles } \\
\text { of rocks, plays as isolated } \\
\text { lowlands forest for seabirds } \\
\text { and wildlife }\end{array}$ & $\begin{array}{l}>75 \% \\
\text { Intertidal mudflat with } \\
\text { mangrove vegetation }\end{array}$ & $\begin{array}{l}>75 \% \\
\text { Sandy beach and isle of rocks in } \\
\text { the sheltered regions }\end{array}$ \\
\hline Uniqueness & $\begin{array}{l}\text { Lobster habitat and turtle nesting } \\
\text { site might be abundant in eastern } \\
\text { parts of Indonesia, but left in } \\
\text { small numbers in Java }\end{array}$ & $\begin{array}{l}\text { Lobster and small isle habitat } \\
\text { might be abundant in eastern } \\
\text { parts of Indonesia, but left in } \\
\text { small numbers in Java }\end{array}$ & $\begin{array}{l}\text { Semi-natural mangrove found } \\
\text { abundant in Indonesia }\end{array}$ & $\begin{array}{l}\text { Lobster and small isle habitat } \\
\text { might be abundant in eastern } \\
\text { parts of Indonesia, but left in } \\
\text { small numbers in Java }\end{array}$ \\
\hline Productivity & $\begin{array}{l}\text { Difficulties in empirical data, but } \\
\text { information about the ease of } \\
\text { lobster fishing from local } \\
\text { fishermen could be represent the } \\
\text { actual conditions }\end{array}$ & $\begin{array}{l}\text { Difficulties in empirical data, } \\
\text { but information about the } \\
\text { ease of lobster fishing from } \\
\text { local fishermen could be } \\
\text { represent the actual } \\
\text { conditions }\end{array}$ & $\begin{array}{l}\text { Difficulties in empirical data, } \\
\text { but information about the } \\
\text { abundant of mangrove crabs } \\
\text { could be represent the actual } \\
\text { conditions }\end{array}$ & $\begin{array}{l}\text { Difficulties in empirical data, } \\
\text { but information about the reef } \\
\text { fish valuable species from local } \\
\text { fishermen could be represent the } \\
\text { actual conditions }\end{array}$ \\
\hline $\begin{array}{l}\text { Migratory } \\
\text { areas }\end{array}$ & Sea turtle and marine mammals & Glass eel & Mangrove & Marine mammals \\
\hline $\begin{array}{l}\text { Endemic/prote } \\
\text { cted species } \\
\text { habitat }\end{array}$ & Sea turtle (IUCN red list) & $\mathrm{n} / \mathrm{a}$ & $\mathrm{n} / \mathrm{a}$ & $\begin{array}{l}\text { High economic value of reef } \\
\text { fishes }\end{array}$ \\
\hline $\begin{array}{l}\text { Spawning } \\
\text { ground }\end{array}$ & Isle of rock and coral reef & $\begin{array}{l}\text { Mangrove, coral reef and } \\
\text { cliff coasts }\end{array}$ & Mangrove & Coral reef and isle of rocks \\
\hline $\begin{array}{l}\text { Nursery } \\
\text { ground }\end{array}$ & Isle of rock and coral reef & $\begin{array}{l}\text { Mangrove, coral reef and } \\
\text { cliff coasts }\end{array}$ & Mangrove & Coral reef and isle of rocks \\
\hline
\end{tabular}

\section{B. Social criteria}

Social acceptance (represented by POKMASWAS performances) could be the most decisive variable, which describe involvement of local communities in the coastal conservation activities. Depth interviews with POKMAWAS in each region show four sites which classified as good management and potentially proposed for the MPA management, includes POKMASWAS Taman Kili Kili (Bay of Panggul Region, Panggul), POKMASWAS Bintang Panikan (Bay of Sumbreng Region, Munjungan), POKMASWAS Kejung (Cengkrong Beach, Karanggandu) and POKMASWAS Karanggongso (eastern part of Bay of Prigi). The following explanations for each variable on social criteria (Table 4).
TABLE IV. ASSESSMENT RESULT FOR ECONOMIC CRITERIA

\begin{tabular}{|l|l|l|l|l|}
\hline \multirow{4}{*}{ Variable } & \multicolumn{4}{|c|}{ Sites selected } \\
\cline { 2 - 5 } & Panggul & Munjungan & \multicolumn{2}{|c|}{ Watulimo } \\
\cline { 2 - 5 } & $\begin{array}{l}\text { T. Kili } \\
\text { Kili }\end{array}$ & Munjungan & Karanggandu & Tasikmadu \\
\hline $\begin{array}{l}\text { Fisheries } \\
\text { importanc } \\
\text { e (LQ) }\end{array}$ & LQ>1 & LQ>1 & LQ>1 & LQ>1 \\
\hline $\begin{array}{l}\text { Tourism } \\
\text { value }\end{array}$ & $\begin{array}{l}\text { Sandy } \\
\text { beach, } \\
\text { sea turtle } \\
\text { conservat } \\
\text { ion }\end{array}$ & $\begin{array}{l}\text { Mangrove } \\
\text { tracking, } \\
\text { boating, } \\
\text { snorkeling, }\end{array}$ & $\begin{array}{l}\text { Mangrove } \\
\text { tracking and } \\
\text { boating }\end{array}$ & $\begin{array}{l}\text { Sandy } \\
\text { beach, } \\
\text { snorkeling, } \\
\text { diving and } \\
\text { boating }\end{array}$ \\
\hline Aesthetics & Sandy & Beach, & Mangrove & Beach, \\
\hline
\end{tabular}




\begin{tabular}{|l|l|l|l|l|}
\hline \multirow{2}{*}{ Variable } & \multicolumn{4}{|c|}{ Sites selected } \\
\cline { 2 - 5 } & Panggul & Munjungan & \multicolumn{2}{|c|}{ Watulimo } \\
\cline { 2 - 5 } & $\begin{array}{l}\text { T. Kili } \\
\text { Kili }\end{array}$ & Munjungan & Karanggandu & Tasikmadu \\
\hline value & beach & $\begin{array}{l}\text { mangrove, } \\
\text { coral reef and } \\
\text { sea stacks }\end{array}$ & & $\begin{array}{l}\text { coral reef, } \\
\text { sea stacks }\end{array}$ \\
\hline $\begin{array}{l}\text { Ease of } \\
\text { access }\end{array}$ & $\begin{array}{l}\text { Direct } \\
\text { access } \\
\text { (collector } \\
\text { road) }\end{array}$ & $\begin{array}{l}\text { Direct access } \\
\text { (collector } \\
\text { road) for } \\
\text { mangrove and } \\
\text { boat for coral } \\
\text { reef }\end{array}$ & $\begin{array}{l}\text { Highway } \\
\text { (JLS) }\end{array}$ & $\begin{array}{l}\text { Highway } \\
\text { and boat }\end{array}$ \\
\hline
\end{tabular}

C. Scoring

Scoring and weighting is performed by simple vector operations, aimed to obtain the conformity difference between regions. The weights on variables referred to MMAF's MPA Site Selection Guidelines for Habitat Conservation of Coastal and Small Islands, (HCCSI or KKP3K, Ind).

TABLE V. VARIABLES AND ENVIRONMENTAL FEATURES BASED ON ADMINISTRATIVE BOUNDARIES

\begin{tabular}{|c|c|c|c|c|c|c|c|c|c|c|}
\hline \multirow{2}{*}{ Subdistrict } & \multirow{2}{*}{ Village } & \multirow{2}{*}{ Biogeografi } & \multicolumn{3}{|c|}{ Ecosystem feature } & \multicolumn{4}{|c|}{ Economic value } & \multirow{2}{*}{$\begin{array}{l}\text { Management } \\
\text { POKMASWAS } \\
\end{array}$} \\
\hline & & & $\mathrm{CR}$ & $\mathrm{M}$ & Cli/Isl & Tou & $\mathrm{CF}$ & Lo. & Meg & \\
\hline \multirow{3}{*}{ 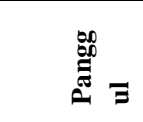 } & Besuki & \multirow{3}{*}{$\begin{array}{l}\text { Bay of } \\
\text { Panggul }\end{array}$} & + & - & + & + & - & + & $\mathrm{n} / \mathrm{a}$ & - \\
\hline & Wonocoyo & & + & - & + & + & + & + & $\mathrm{n} / \mathrm{a}$ & Kili Kili \\
\hline & Nglebeng & & + & - & + & - & - & + & $\mathrm{n} / \mathrm{a}$ & - \\
\hline \multirow{7}{*}{ 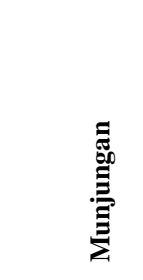 } & Ngulung W. & \multirow{6}{*}{$\begin{array}{l}\text { Bay of } \\
\text { Sumbreng }\end{array}$} & + & - & + & - & - & + & $\mathrm{n} / \mathrm{a}$ & - \\
\hline & Ngulung K. & & + & - & + & - & - & + & $\mathrm{n} / \mathrm{a}$ & - \\
\hline & Craken & & + & - & - & - & - & + & $\mathrm{n} / \mathrm{a}$ & - \\
\hline & Masaran & & - & + & + & + & - & + & $\mathrm{n} / \mathrm{a}$ & - \\
\hline & Munjungan & & + & + & + & + & + & + & + & Bintang Panikan \\
\hline & Tawing & & - & - & - & + & + & + & $\mathrm{n} / \mathrm{a}$ & Bintang Panikan \\
\hline & Bendoroto & & + & - & + & - & + & + & + & - \\
\hline \multirow{3}{*}{$\stackrel{\bar{\Xi}}{\stackrel{\Xi}{E}}$} & Karanggandu & \multirow{3}{*}{ Bay of Prigi } & + & + & - & + & + & + & $\mathrm{n} / \mathrm{a}$ & Kejung Samudera \\
\hline & Prigi & & - & - & - & + & - & + & $\mathrm{n} / \mathrm{a}$ & - \\
\hline & Tasikmadu & & + & - & + & + & + & + & + & Karanggongso \\
\hline
\end{tabular}

TABLE VI. VALUES FROM EACH CRITERIA

\begin{tabular}{|c|c|c|c|c|c|}
\hline \multirow{3}{*}{ No. } & \multirow{3}{*}{ Variables } & \multicolumn{4}{|c|}{ Proposed areas for MPA/MCA } \\
\hline & & \multirow{2}{*}{$\begin{array}{l}\text { Panggul } \\
\text { Kili Kili }\end{array}$} & \multirow{2}{*}{$\begin{array}{l}\text { Munjungan } \\
\text { Munjungan }\end{array}$} & \multicolumn{2}{|c|}{ Watulimo } \\
\hline & & & & Karanggandu & Tasikmadu \\
\hline A & EKOLOGI & & & & \\
\hline 1 & Diversity & 8 & 12 & 8 & 12 \\
\hline 2 & Naturalness & 12 & 12 & 4 & 12 \\
\hline 3 & Ecological linkage & 12 & 12 & 12 & 12 \\
\hline 4 & Representativeness & 9 & 9 & 9 & 9 \\
\hline 5 & Uniqueness & 6 & 6 & 3 & 6 \\
\hline 6 & Productivity & 6 & 9 & 6 & 9 \\
\hline 7 & Migratory areas & 9 & 9 & 3 & 6 \\
\hline 8 & Endemic/protected species habitat & 6 & 6 & 3 & 6 \\
\hline
\end{tabular}




\begin{tabular}{|c|c|c|c|c|c|}
\hline \multirow{3}{*}{ No. } & \multirow{3}{*}{ Variables } & \multicolumn{4}{|c|}{ Proposed areas for MPA/MCA } \\
\hline & & \multirow{2}{*}{$\begin{array}{c}\text { Panggul } \\
\text { Kili Kili }\end{array}$} & \multirow{2}{*}{$\begin{array}{c}\text { Munjungan } \\
\text { Munjungan }\end{array}$} & \multicolumn{2}{|c|}{ Watulimo } \\
\hline & & & & Karanggandu & Tasikmadu \\
\hline 9 & Spawning ground & 8 & 12 & 4 & 12 \\
\hline 10 & Nursery ground & 6 & 9 & 9 & 6 \\
\hline B & \multicolumn{5}{|l|}{ SOSIAL } \\
\hline 11 & Social acceptance & 3 & 3 & 2 & 2 \\
\hline 12 & Threat & 2 & 1 & 2 & 2 \\
\hline 13 & Potential conflict of interest & 3 & 3 & 1 & 1 \\
\hline 14 & Local customs & 1 & 1 & 1 & 1 \\
\hline $\mathrm{C}$ & \multicolumn{5}{|l|}{ EKONOMI } \\
\hline 15 & Fisheries importance (LQ) & 6 & 6 & 6 & 6 \\
\hline 16 & Tourism value & 4 & 6 & 4 & 6 \\
\hline 17 & Aesthetics value & 4 & 6 & 4 & 6 \\
\hline 18 & Ease of access & 6 & 4 & 6 & 6 \\
\hline & & 111 & 126 & 87 & 120 \\
\hline & SCORE & 1,01 & 1,18 & $\mathbf{0 , 8 5}$ & 1,08 \\
\hline
\end{tabular}

The results show a high suitability for category HCCI, considering its geomorphological and ecological features. Selection and recommendation of Marine Protected Area (MPA) or Marine Conservation Areas (MCA) based on ecological and economic values in the coastal zones, includes coastal land and coastal water. Administration boundary of the coastal villages used to identify conservation management (POKMASWAS) and to identify potential threat on the base of coast land. In fact, the boundary area of MPA or MCA can surpass the administrative boundaries of the coastal village, because of the conservation area is terms as ecological region. From these considerations, maps of proposed MPA are as follows.

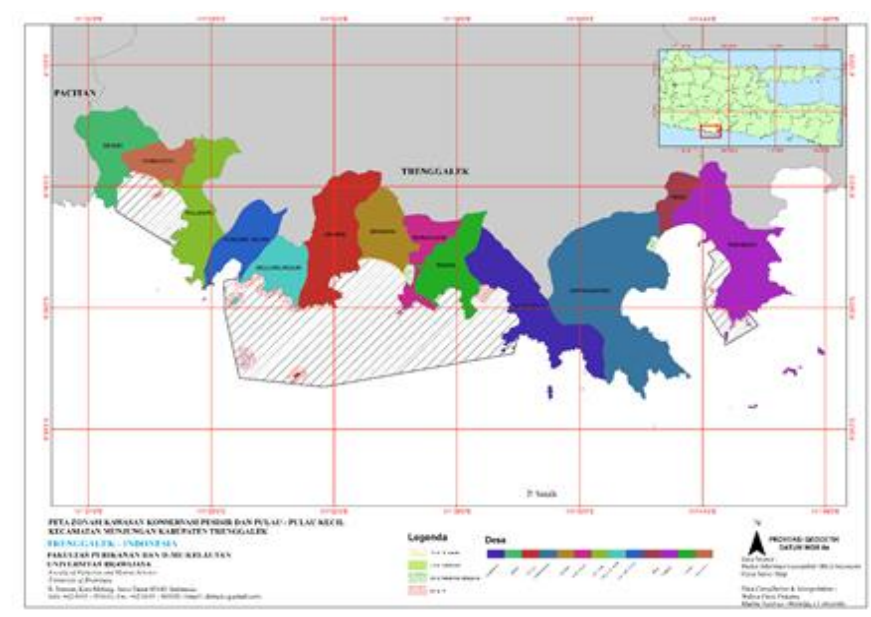

Fig. 5. MPA sites recommendation in Trenggalek.

\section{CONCLUSIONS AND SUGGESTIONS}

Based on the results of this research show high suitability areas for MPA includes Wonocoyo, Munjungan, Karanggandu and Karanggongso. Each site has a high value in ecological criteria (ecosystem and biodiversity), social criteria (social acceptance) and 
economic criteria (importance to species and value for marine tourism).

\section{ACKNOWLEDGEMENTS}

This activity is funded by Conservation Program FY 2016 of Department of Marine Affairs and Fisheries, East Java Province in collaboration with BPP Faculty of Fisheries and Marine Science, Brawijaya University.

\section{REFERENCES}

[1] D. R. Lyzenga, 1978, "Passive remote sensing techniques for mapping water depth and bottom features", Applied Optics, 17: 379-383.

[2] FAO (2008), "The state of world fisheries and aquaculture," Rome, Italy, FAO Fisheries and Aquaculture Department.

[3] G. Kelleher, 1999, "Guidelines for Marine Protected Areas. Gland, Switzerland and Cambridge," UK: IUCN — The World Conservation Union. xxiv $+107 \mathrm{pp}$.

[4] KKP, 2016, "Data dan Informasi, Kriteria, Pertimbangan dan Penentuan, Delineasi serta Pengaturan Kawasan Konservasi Dalam RZWP3K," Direktorat KKJI.

[5] Roberts, Callum, 2007, "The Unnatural History of The Sea,'Islandpress.

[6] R.V. Salm, John Clark, and Erkki Siirila, (2000), "Marine and Coastal Protected Areas: A guide for planners and managers," IUCN. Washington DC. Xxi + 371pp.

[7] S.English, , C.Wilkinson, and V. Baker, 1997, "Survey Manual for Tropical Marine Resources," 2nd Edition. (Townsville: Australian Institute of Marine Science).

[8] T. W. Clark, P.C. Paquet, A. P. Curlee, 1996, "Conservation Biology" 